\title{
Seismic vulnerability assessment of buildings of Patna by rapid visual screening
}

\author{
Siddharth $^{1^{*}}$ and Ajay Kumar Sinha ${ }^{2}$ \\ $\mathrm{PhD}$. Research Scholar, Department of Civil Engineering, National Institute of Technology, Patna, India ${ }^{1}$ \\ Professor, Department of Civil Engineering, National Institute of Technology, Patna, India ${ }^{2}$
}

Received: 07-September-2021; Revised: 23-January-2022; Accepted: 25-January-2022

(C)2022 Siddharth and Ajay Kumar Sinha. This is an open access article distributed under the Creative Commons Attribution (CC BY) License, which permits unrestricted use, distribution, and reproduction in any medium, provided the original work is properly cited.

\begin{abstract}
Many damaging earthquakes have occurred in various regions of India in past few decades. It has affected large scale loss to life and property. The city of Patna is located in seismic Zone IV, according to IS1893 making it substantially vulnerable to earthquake. Such areas need proper study to decide preventive measures for avoiding any probable disaster. Seismic vulnerability is one of the most crucial parameters for structural safety assessment. According to most of the guidelines used worldwide, a three-stage process of evaluation is generally adopted. The first level of evaluation is rapid visual screening (RVS). This paper summarizes the RVS carried out in 201 buildings of Patna. The buildings have been ranked according to the number of storeys, grade of damage, and year built. The study shows poor maintenance history of buildings. Also, the buildings were found to be constructed not as per codal provisions. The result shows the need for retrofitting of buildings after further study.
\end{abstract}

\section{Keywords}

Seismic vulnerability, Rapid visual screening, Damageability, Non-engineered buildings.

\section{Introduction}

The seismic vulnerability of any structure is its inability to withstand future earthquakes [1, 2]. Severe damages to the structure have occurred due to past earthquakes, resulting in loss of life and money. Buildings constructed in India before implementing seismic codes are most vulnerable and have resulted in a significant loss. India is a country that is very seismically active due to its location and demography. Around $80 \%$ population of India lives in earthquake-prone seismic zones [3]. Bhuj earthquake occurred in 2001, which resulted in the collapse of reinforced concrete buildings in Bhuj and Gandhidham [4, 5]. The earthquake in Kashmir in 2005 resulted in damage to stone masonry buildings [6]. The occurrence of the Sikkim earthquake in the year 2011 resulted in the deterioration of nonengineered reinforced concrete buildings [7]. So, because of these failures, a seismic vulnerability assessment needs to be done. Seismic vulnerability assessment is the process of evaluation to find out the deficiencies of the structure.

*Author for correspondence

61
Much research has been done on seismic vulnerability assessment methods by various scientists around the world [8]. The casualty and magnitude during occurred earthquakes are shown in Figure 1 and Figure 2 respectively. The Seismic vulnerability assessment is a three-step process in different codes namely, (1) Rapid visual screening (RVS) (2) Preliminary assessment method or simplified assessment (3) Detailed assessment method.

\section{Rapid visual screening (RVS)}

This is a fast method of assessment. The screening is usually done within 10-15 methods. In this, various parameter is taken into account as per the RVS forms. Trained surveyors carry out the RVS process. The main aim of this procedure is to rank buildings and also to filter out which buildings need further evaluation. In this method grading is usually done.

Preliminary assessment method or simplified assessment

In this method models of buildings are drawn along with layout of columns and beams. This method includes various type of strength checks and in-depth evaluations of buildings are done. 


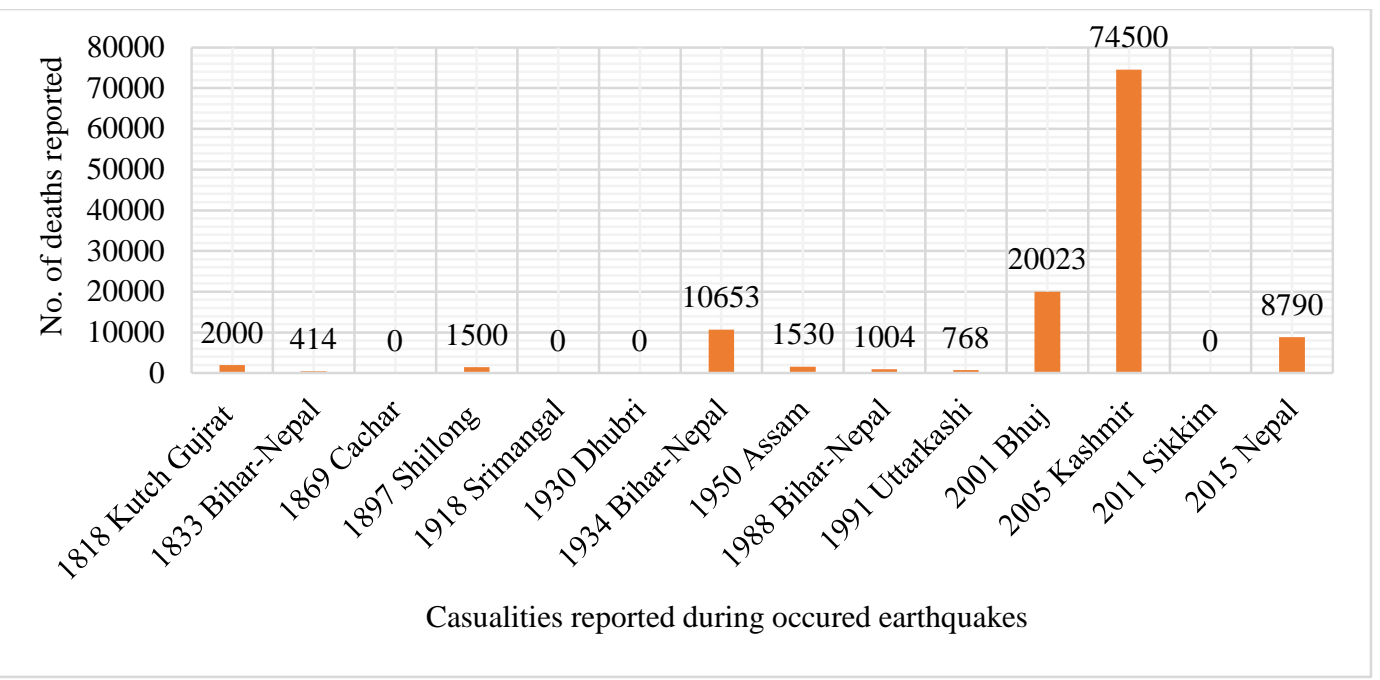

Figure 1 Death reported in India due to significant earthquakes (Source: Indian Meteorological Department)

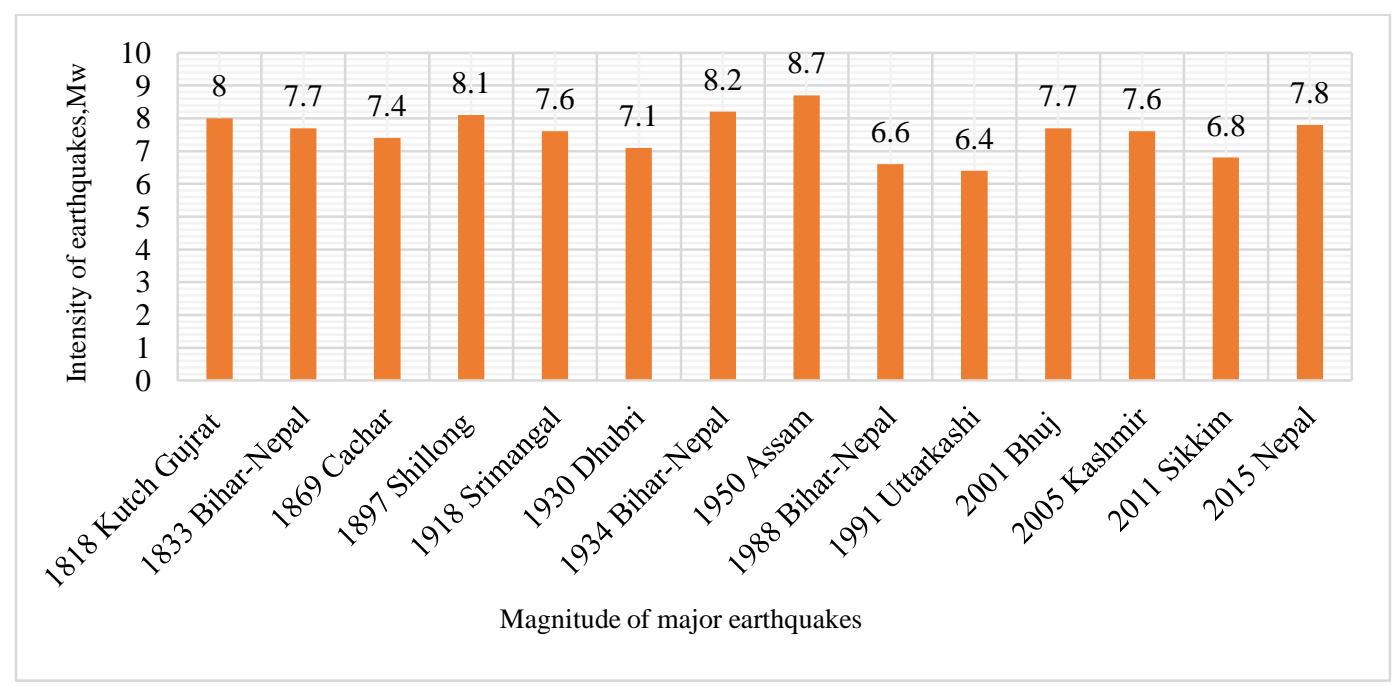

Figure 2 Magnitude of earthquakes in India (Source: Indian Meteorological Department)

\section{Detailed Evaluation}

This is the third phase of evaluation. It requires linear or nonlinear analyses of the building based on asbuilt dimensions. This phase involves calculation of moments and flexural capacity of buildings. Also, storey drift calculation is done. The flowchart for the three-step assessment procedure is shown in Figure 3. The main objective of current work is to find out the current vulnerability status of buildings of this area and identify which building needs further evaluation. The motivation behind the correct work is the number of damages due to recurring earthquakes in this city in past 100 odd years and how to reduce it. The limitation of the current study is RVS of selected buildings of Patna. 


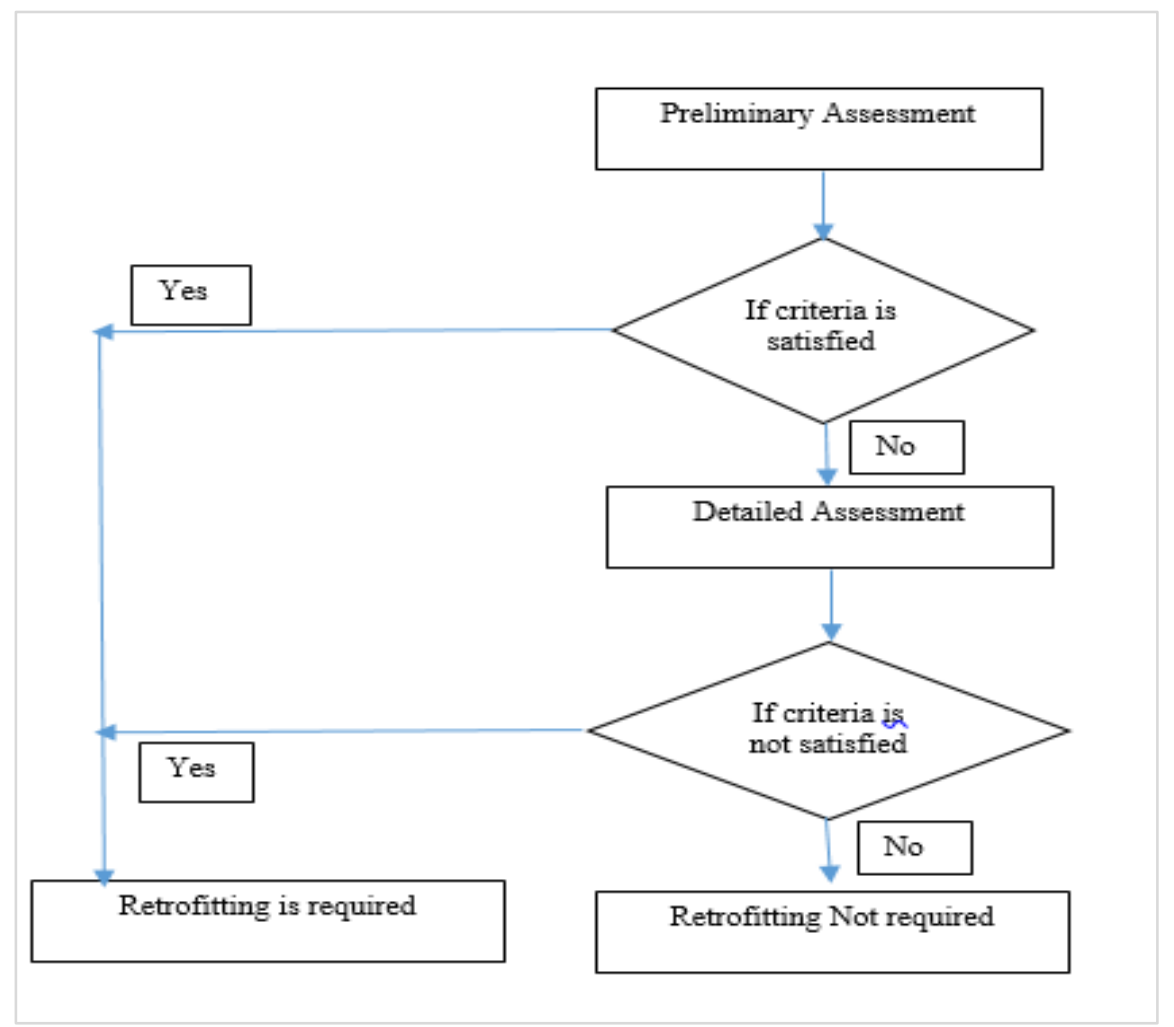

Figure 3 Flow chart of vulnerability assessment process

\section{Literature review}

Mulas et al. [9] studied vulnerability of torsionally deformable reinforced concrete buildings of Italy. In this study it was found that buildings were not built as per seismic provision. The advantages of different retrofitting methods were concluded.

Haryanto et al. [10] conducted RVS of buildings in Indonesia. The conclusion from the study is that a safety policy of educational buildings needs to be made and the vulnerable buildings can be retrofitted.

Ruggieri et al. [11] did study on priority of most vulnerable school buildings and proposed a methodology for assessment of buildings. The result showed that the proposed methodology can be used for vulnerability assessment efficiently.

Reddy et al. [12] did study the risk vulnerability of Chennai. A total number of 100 buildings from Chennai were surveyed. Pushover analysis was done on selected buildings. After the analysis, it was concluded that detailed study for the city needs to be done.
Parmar et al. [13] did vulnerability assessment of buildings of Surat. In the study RVS of 690 buildings were done It was concluded that almost $80 \%$ buildings were in good condition.

Calvi et al. [14] did review of various methodology proposed in past 30 years. In the study it was emphasized that for assessment of vulnerability in a loss model, the main parameter is sound algorithm.

Ramly et al. [15] conducted a RVS of 1166 number of buildings in Pahang, Malaysia. Out of which 308 number of buildings required detailed investigation.

Sarraz et al. [16] conducted RVS of 310 number of buildings in Chandgaon, Bangladesh. In this study the vulnerability was compared with the performance score of the buildings. It was concluded that the vulnerable buildings need to be repaired and restored.

Modi and Mohan [17] conducted RVS of 100 number of reinforced concrete buildings in Rambaug, Ahmedabad, after the Bhuj earthquake. In this study, it was concluded that $88 \%$ of the building had a soft storey, $55 \%$ of the building had heavy overhangs, and $48 \%$ had vertical irregularity. 
Sadat et al. [18] studied 2007 number of buildings in the Dhanmondi, Lalmatia, and Mohammadpur areas of Dhaka. Out of which 1082 buildings were RCC, and 975 numbers of the building were unreinforced masonry buildings. Total 476 buildings out of 1082 buildings had a soft storey. It was concluded that the majority of buildings did not follow codal provisions and had no proper emergency exit.

Joshi and Kumar [19] conducted RVS of 3339 number of buildings in Mussoorie, Uttarakhand. Out of which, around $20 \%$ of buildings (623 buildings) were having grade 5 damage (G5) and grade 4 (G4) damage. Also, about $19 \%$ of buildings (587 buildings) were having grade 4 (G4) damage and grade 3 (G3) damage.

Dutta et al. [20] did a damage assessment of buildings after the 2015 Gorkha earthquake. In this study, it was decided to judge the earthquake preparedness of buildings in the city of Patna. It was concluded that many buildings need retrofitting measures, especially for non-engineered buildings.

Sarmah and Das [21] conducted RVS of 100 number of buildings of Guwahati. The buildings were categorized according to nine different parameters. The study provided details according to which retrofitting and replacement may be decided further by municipal authorities of Guwahati.

Rautela et al. [22] conducted a RVS of 6206 numbers of buildings in Mussoorie and Nainital town of Uttarakhand. In this study, it was concluded $14 \%$ of buildings of Nainital and $18 \%$ of buildings of Mussoorie are of Grade 5(G5) damage category. These buildings are hospital and lifeline buildings that might be vulnerable in case of significant earthquakes.

Shakya et al. [23] did damage assessment of buildings of Bhaktapur city of Nepal after the 2015 Gorkha earthquake. In this study, the main causes of building damage during the earthquake were described. Also the remedial measures after earthquake destruction were recommended.

Aldemir et al. [24] studied about the seismic risk assessment of buildings. In this study, a method was developed for the risk assessment of unreinforced buildings.

Halder et al. [25] studied about damage of existing buildings in North East. The result with the help of fragility curve shows the unreinforced masonry (URM) building present are most vulnerable ones and detailed study is required for more accurate results [26]. From the literature review it is clear that older buildings are deficient and hence require further detailed evaluation. After the evaluation of buildings, retrofitting needs to be done.

\section{Methodology}

\subsection{RVS procedure}

The RVS procedure followed in this research work includes the following is shown in Figure 4. Firstly, the data collection form is selected from existing RVS methods. Then the area to be screened is chosen and the secondary data such as soil data, plan etc. are collected. A team of surveyors is formed. They are trained and sent to field for data collection. The primary data of the survey includes the sketch of the building, no of storeys, plan irregularity, vertical irregularity and photographs of the buildings etc. Thereafter the collected data are stored in computer and analysed.

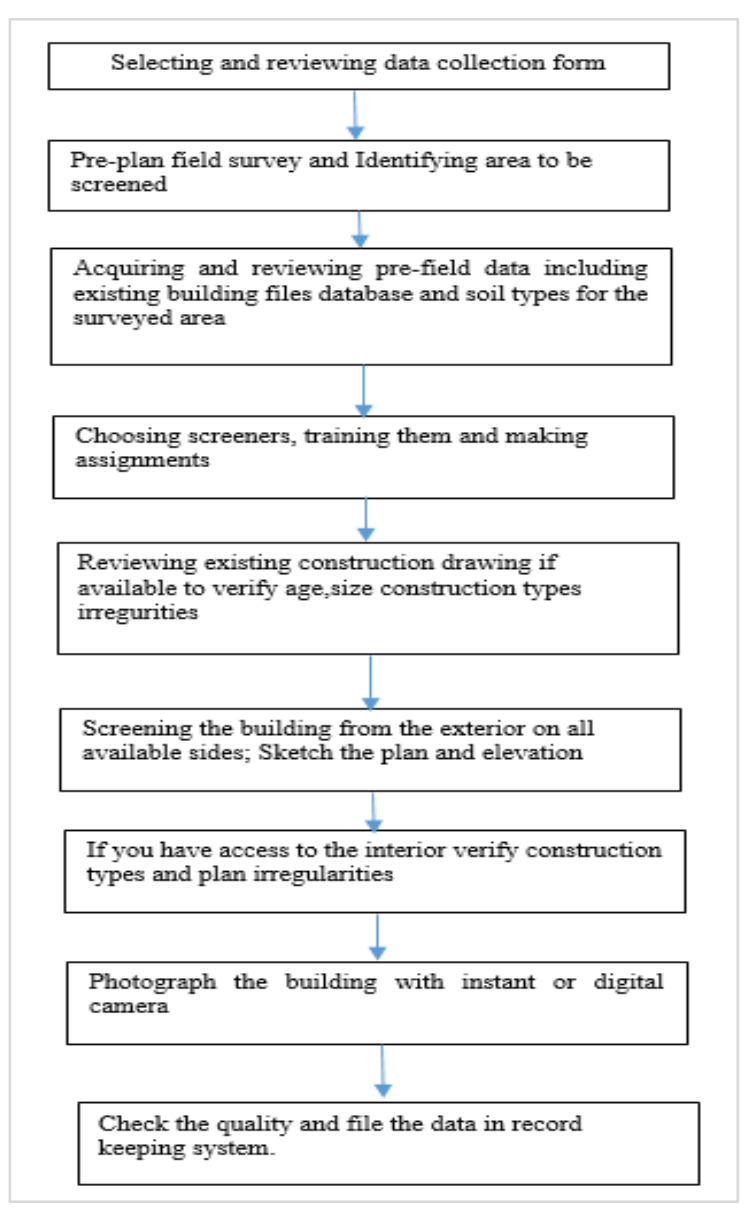

Figure 4 Flowchart for the RVS procedure 
3.20verview of the study area

The study was conducted in the city of Patna. Few localities of Patna such as Bailey Road, Circular Road, Deshratna Marg, Mangles Road, Polo Road, Shastri Nagar, Strand Road, and Taylor Road were selected for the survey work. The city of Patna lies in seismic zone IV according to the classification of IS 1893: 2016. Patna is the capital city of Bihar, which lies on the Indo-Nepal border. Bihar is located in high seismic zones due to its location on a tectonic plate in the Himalayas. Bihar has total no of 38 districts, out of which 8 district lies in Zone V and 24 district lies in zone IV. The state of Bihar has witnessed major earthquakes in the year 1833, 1934 and 1988 with loss of life and money [27, 28]. The typology of surveyed buildings are unreinforced masonry buildings. Figure 5 is the location of study area taken from the google map of Patna and roads surveyed are highlighted in yellow.

\subsection{Data collection}

Primary data was collected through RVS by field visit and secondary data was collected from junior engineers of building construction department, Goverment of Bihar, Patna. RVS survey sheet as developed in IS13935:2009[29] was used (Appendix II). The RVS Survey sheet is an empirical method of assessment. The details of locality of buildings are tabulated in Table 1. Figure 6, Figure 7, Figure 8, Figure 9 and Figure 10 are different photographs of building no.-1, Deshratna Marg. This building used to be the residence of Late Karpoori Thakur, former chief minister of Bihar and currently used as museum.

Figure 6 is the front view of the building. Figure 7 shows spalling in ceiling inside the buildings. These are most common problems in URM buildings. Figure 8 shows the dampness on the walls of the buildings. This may have deteriorating effects on the strength of the buildings. Figure 9 represents walls with plaster damage. Figure 10 shows corrosion of reinforcement of roofs.

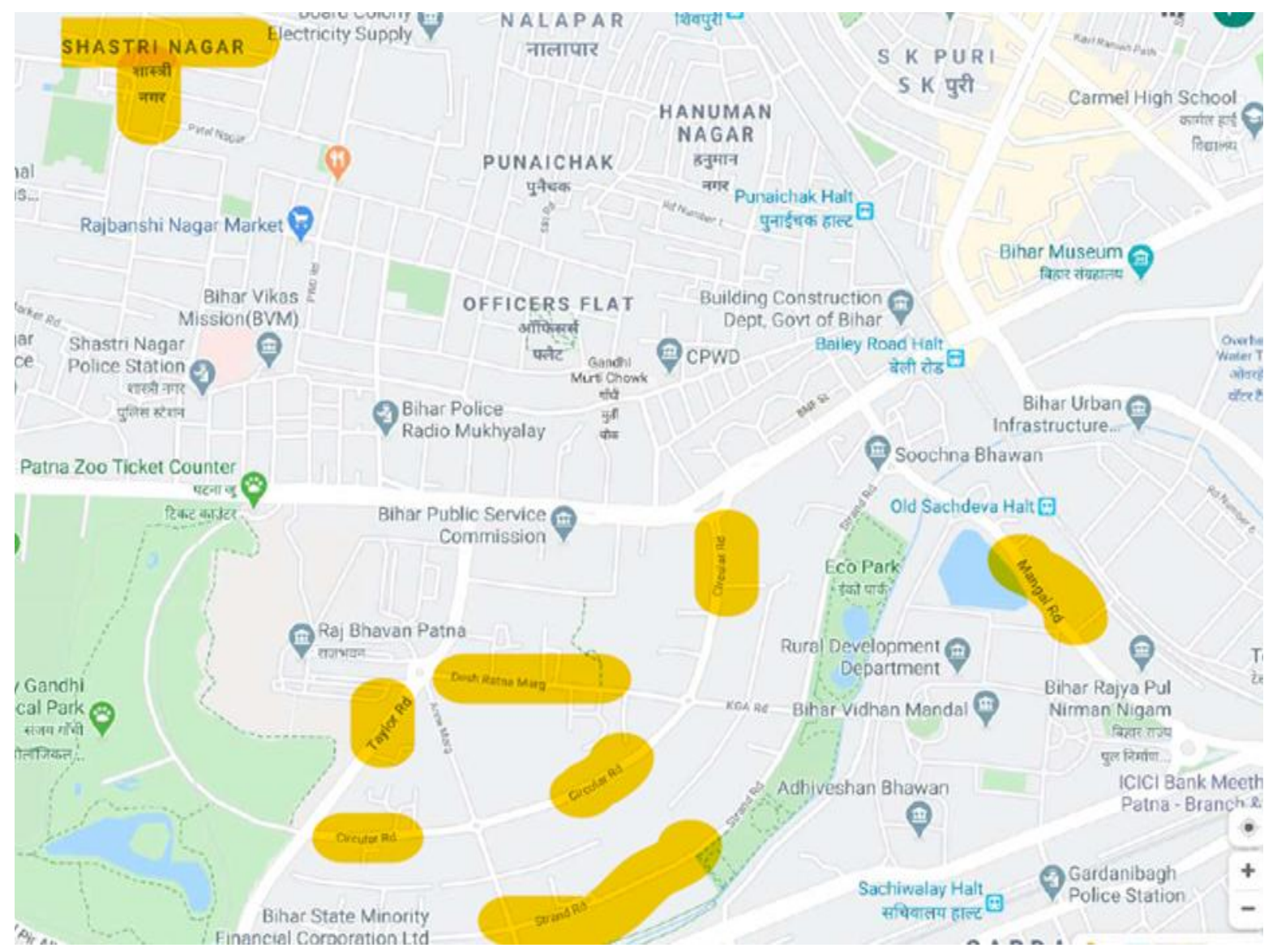

Figure 5 Location of study area (Highlighted in yellow) 
Siddharth and Ajay Kumar Sinha

Table 1 List of surveyed buildings

\begin{tabular}{llll}
\hline Name of the locality & Residential & Office & Total \\
\hline Quaters of Bailey Road & 03 & 03 & 06 \\
\hline Quarters of Circular Road & 06 & 00 & 06 \\
\hline Quarters of Deshratna Marg & 03 & 02 & 05 \\
\hline Quarters of Mangles Road & 06 & 07 & 13 \\
\hline Quarters of Polo Road & 08 & 00 & 08 \\
\hline Quarters of Shastri Nagar & 131 & 00 & 131 \\
\hline Quarters of Strand Road & 29 & 00 & 29 \\
\hline Quarters of Taylor Road & 03 & 00 & 03 \\
\hline
\end{tabular}

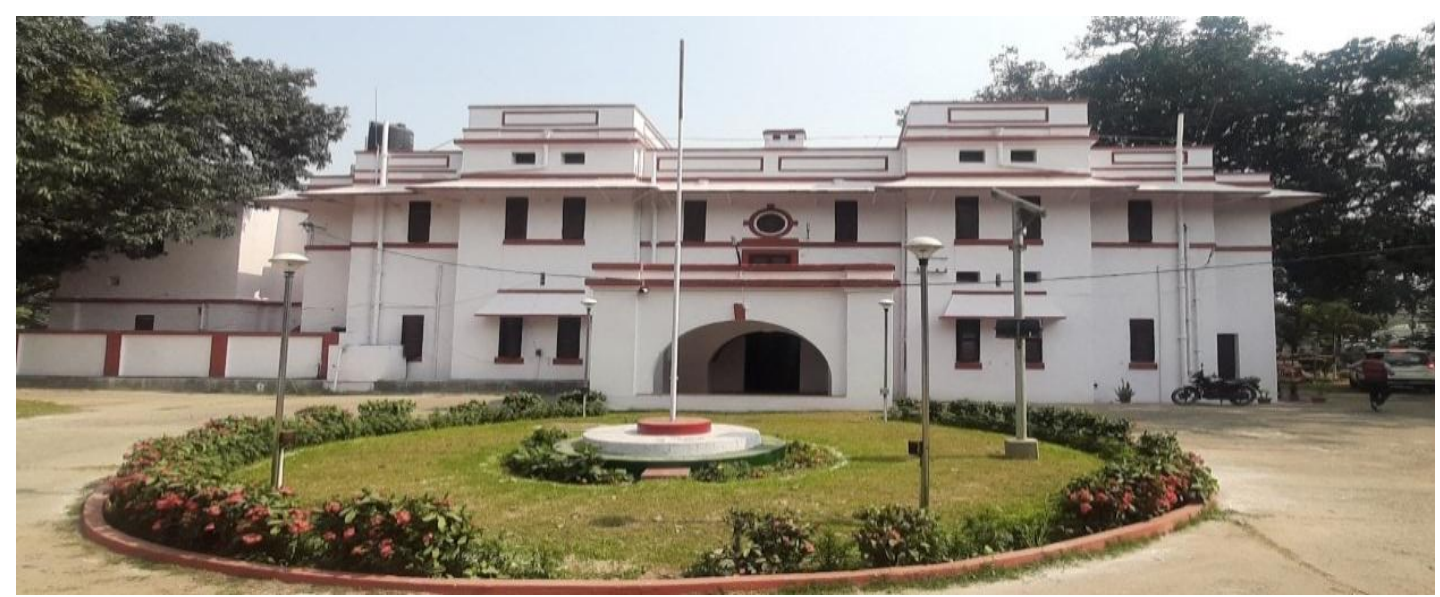

Figure 6 Front view of main buildings of 1, Desh Ratna Marg (Residence of Late CM Karpoori Thakur)

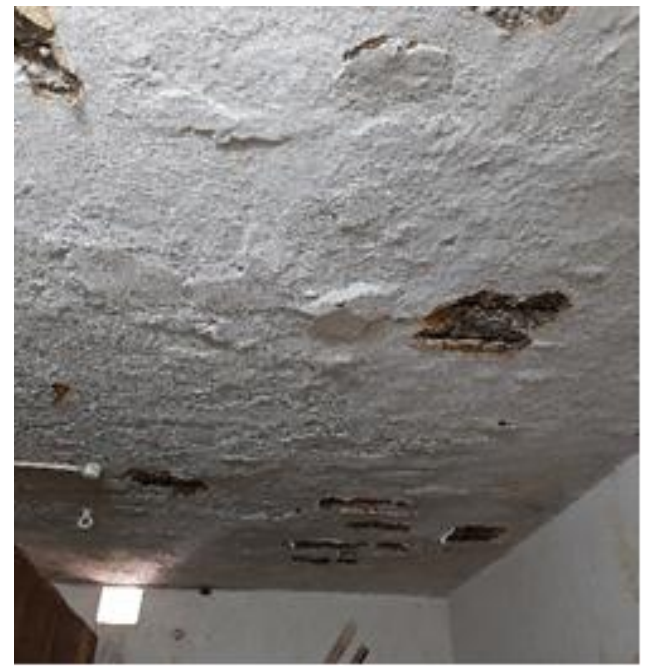

Figure 7 Spalling in ceiling

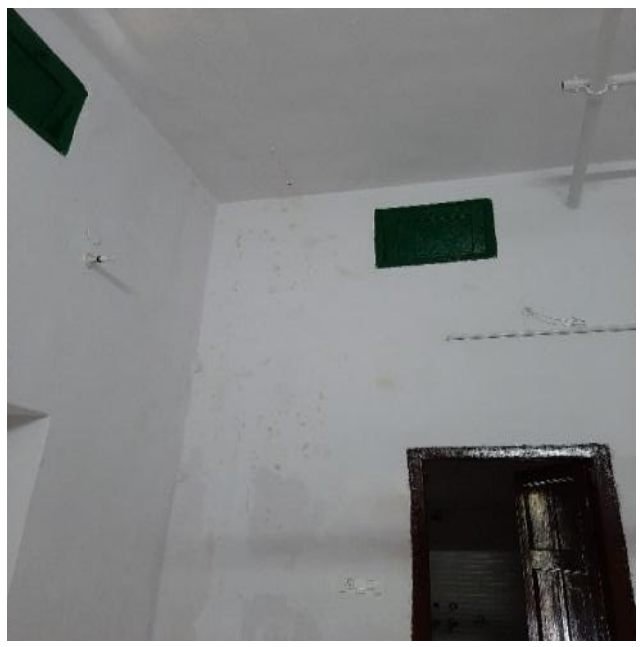

Figure 8 Dampness on walls 


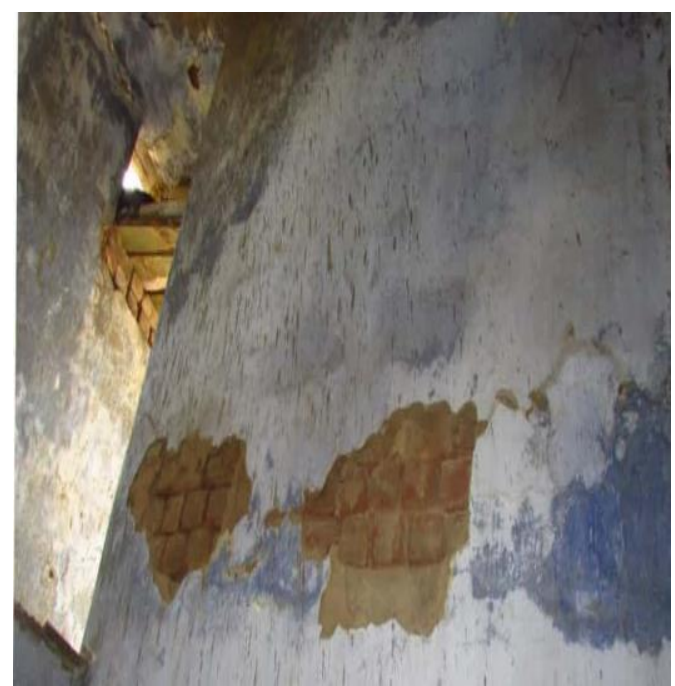

Figure 9 Deterioration of walls

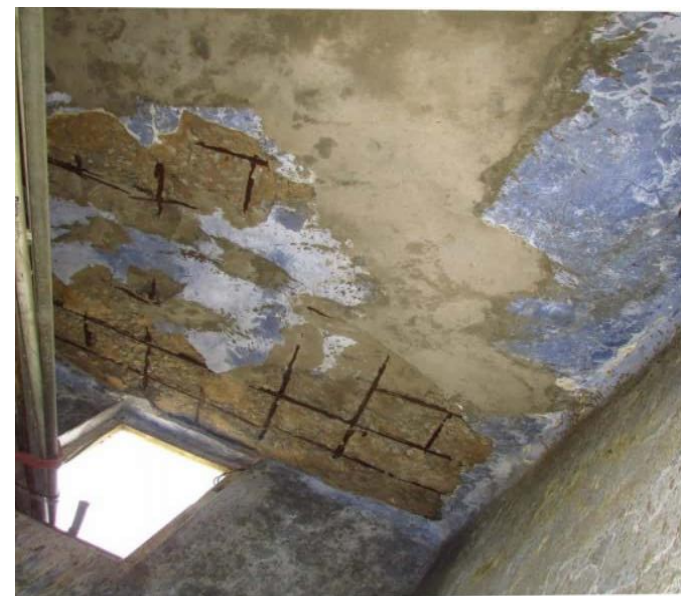

Figure 10 Corrosion reinforcement of the ceiling

3.4Factors affecting the damageability of buildings

- Irregularity in plan as well as elevation could leads to higher grade of damageability.

- Fire exits provided in the buildings were checked.

- Spalling and dampness were checked which had influence on damage grades.

- Corrosion of reinforcement

\section{Results}

In this research study damages in buildings were hair line cracks, major cracks and spalling of plasters for different grades of damage. There was dampness in building as well as cracks at roof and lintel level. The buildings were checked for irregularities. The results of the current study are classified based upon damageability, height of the building and age of the building.

67

\section{Damageability grades}

A total number of 201 buildings were surveyed and the damageability grades for each of buildings were found out using the RVS forms. Survey form as per IS 13935:2019 were used for the classification of grades. All the surveyed buildings were masonry type buildings. The Table 2 below shows the grades of different buildings

Table 2 Buildings in different damage grade categories

\begin{tabular}{ll}
\hline Grade of damageability & No of buidings \\
\hline Grade 1 & 00 \\
\hline Grade 2 & 01 \\
\hline Grade 3 & 152 \\
\hline Grade 4 & 46 \\
\hline Grade 5 & 02 \\
\hline Total & 201 \\
\hline
\end{tabular}

The Figure 11 shows the pie chart for comparison between damageability grade and percentage no of buildings. The percentage of grade 3 buildings were more than grade 4 damage buildings. Also, there were no grade 1damage buildings. The Table 3 shows the classification of surveyed buildings based upon the height of the buildings. The height of the building also affects the vulnerability of building. The Figure 12 shows the pie chart for comparison between storey height and percentage no of buildings. The percentage of surveyed buildings having height $>1$ was more than single story building. Also, there were few buildings of single storey.

Table 3 Storey height of the surveyed buildings

\begin{tabular}{ll}
\hline Height of the buildings & No. of buildings \\
\hline $\mathrm{G}$ & 23 \\
\hline $\mathrm{G}+1$ & 46 \\
\hline $\mathrm{G}+2$ & 132 \\
\hline Total & 201 \\
\hline
\end{tabular}

The Figure 12 shows the pie chart for comparison between storey height and percentage no of buildings. The percentage of surveyed buildings having height $>1$ was more than single story building. Also, there were few buildings of single storey. The Table 4 shows the classification of surveyed buildings based upon the age of the buildings. The age of the building also affects the vulnerability of building. The topology of surveyed building which were built in between 1927 and 1950 were made of lime mortar and roof were flat roof. Also, some roofs were made of timber which had impact on the condition of building. The Figure 13 shows the pie chart for comparison between age of building and percentage no. of buildings. 
The percentage of surveyed buildings built between 1927 and 2000.The building where not complaint to current Indian standard code and hence are more vulnerable to seismic hazards.
A complete list of abbreviations is shown in Appendix I.

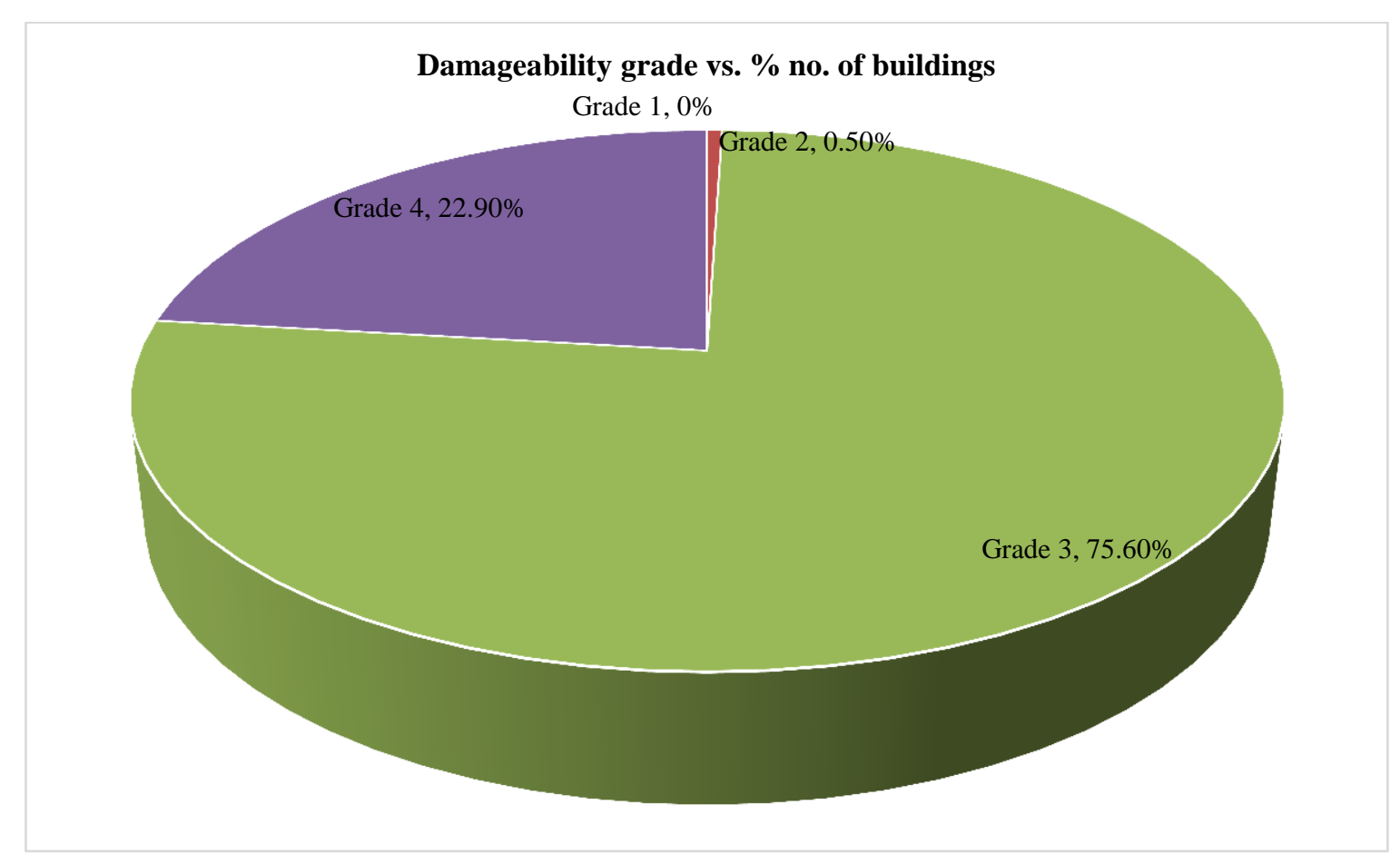

Figure 11 Pie chart of classification based upon damageability grade

Height of buildings vs. \% no. of buildings

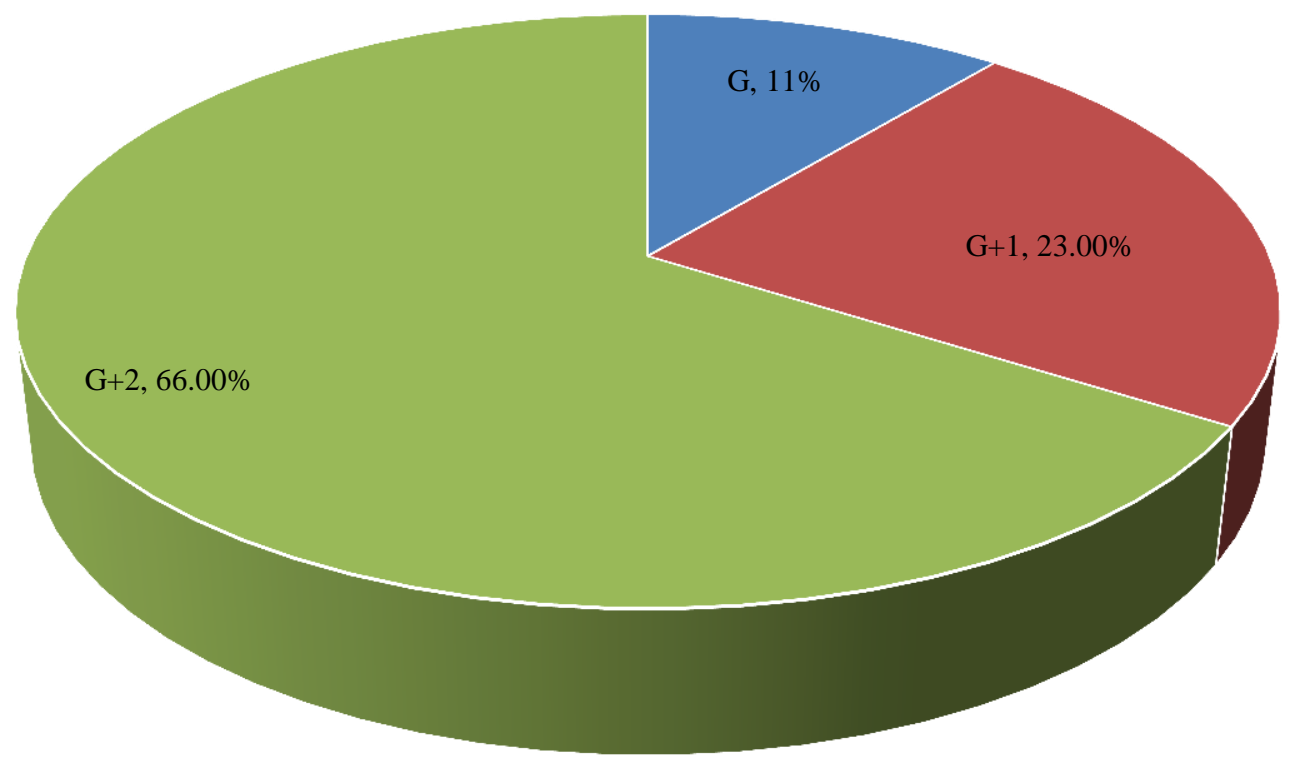

Figure 12 Pie chart of classification based upon Height of building 
Table 4 Buildings in different damage grade categories

\begin{tabular}{ll}
\hline Year built & No. of buildings \\
\hline 1927 & 02 \\
\hline 1930 & 03 \\
\hline 1934 & 03 \\
\hline 1950 & 36 \\
\hline 1956 & 01 \\
\hline 1960 & 10 \\
\hline 1962 & 20 \\
\hline 1964 & 98 \\
\hline 1965 & 03 \\
\hline 1985 & 20 \\
\hline 2000 & 05 \\
\hline Total & 201 \\
\hline
\end{tabular}

\section{Discussion}

The vulnerability of existing buildings depends upon the maintenance history, provision of fire exits and implementation of codal provisions. The existing URM buildings in the current research work are vulnerable due to above factors. The scope of the current research is limited to RVS of 201 number of buildings located in Bailey Road, Circular Road, Deshratna Marg, Mangles Road, Polo Road, Shastri Nagar, Strand Road, and Taylor Road of Patna. The surveyed buildings had no fire exits which may prove to be fatal during fire hazards. Also, higher damage grade 4 and grade 5 are due to age of buildings and poor maintenance conditions. There were buildings having timber roof which may be vulnerable due to decay in course of time. There was corrosion in reinforcement in roofs of few buildings which may be disastrous for occupants in case of failure. The result of current work will pave way for decision to be taken for further study and action to be taken thereof.

\section{Conclusion and future work}

During RVS survey it was observed that $11.4 \%$ of buildings have a ground floor, $22.9 \%$ of buildings are $\mathrm{G}+1$, and $65.7 \%$ of buildings are $\mathrm{G}+2$. The majority of buildings surveyed are built between 1927 and 2000. Most of buildings had spalling and dampness in walls. Vegetation growth in and around the structure was seen which may have impact on vulnerability. Also, there were many visible vertical and diagonal cracks in the buildings. These factors had impact of damage grades. From the study it has been found that $1 \%$ of buildings are Grade 5, 23\% of buildings are Grade 4, 75.6\% of buildings are Grade 3 and $0.04 \%$ of buildings are Grade 2. In future, further detailed study of Grade 4 and Grade 5

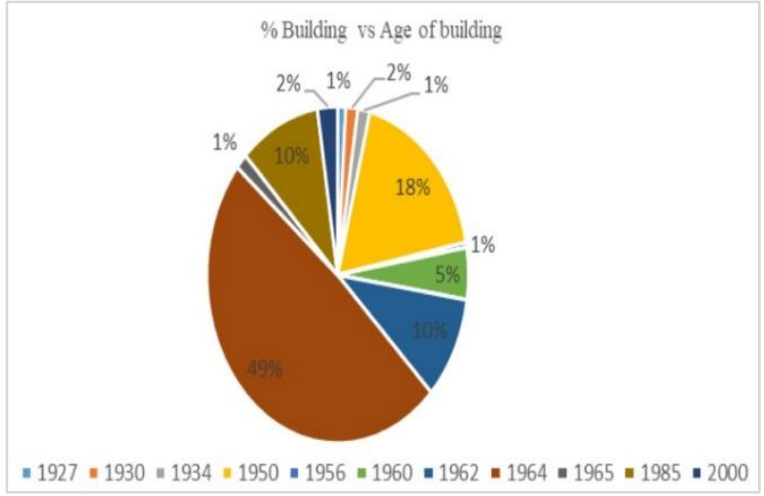

Figure 13 Classification of building based on Age of building

buildings needs to be done after which retrofitting measures can be decided.

\section{Acknowledgment}

None.

\section{Conflicts of interest}

The authors have no conflicts of interest to declare.

\section{Authors contribution statement}

Siddharth: Conceptualization, data collection, analysis, writing- review and editing. Ajay Kumar Sinha: Writingoriginal draft, analysis and interpretation of results.

\section{References}

[1] Cockburn G, Tesfamariam S. Earthquake disaster risk index for Canadian cities using bayesian belief networks. Georisk: Assessment and Management of Risk for Engineered Systems and Geohazards. 2012; 6(2):128-40.

[2] Hill M, Rossetto T. Comparison of building damage scales and damage descriptions for use in earthquake loss modelling in Europe. Bulletin of Earthquake Engineering. 2008; 6(2):335-65.

[3] Kumar RP, Murty CV. Earthquake safety of houses in India: understanding the bottlenecks in implementation. Indian Concrete Journal. 2014.

[4] https://sudhirjain.info/INL_005.pdf. Accessed 05 September 2021.

[5] Murthy CVR, Goel RK, Goyal A, Jain SK, Sinha R, Durgesh CR, et al. Reinforced concrete structures. Earthquake Spectra. 2002; 18(1):149-85.

[6] Naeem A, Ali Q, Javed M, Hussain Z, Naseer A, Ali SM, et al. First report on the Kashmir earthquake of October 8, 2005. EERI Special Earthquake Report. 2005.

[7] Murty CV, Raghukanth ST, Menon A, Goswami R, Vijayanarayanan AR, Gandhi SR, et al. The Mw 6.9 Sikkim-Nepal border earthquake of September 18, 2011. EERI Newsletter, EERI Special Earthquake Report. 2012:1-4. 
[8] Rai DC. Review of documents on seismic evaluation of existing buildings. Department of Civil Engineering, Indian Institute of Technology Kanpur India. 2005.

[9] Mulas MG, Stroffolini L, Martinelli P. Vulnerability and retrofitting of torsionally deformable RC buildings: a case study. Structures. 2021; 32:861-75. Elsevier.

[10] Haryanto Y, Hu HT, Han AL, Hidayat BA, Widyaningrum A, Yulianita PE. Seismic vulnerability assessment using rapid visual screening: case study of educational facility buildings of jenderal soedirman university, Indonesia. Civil Engineering Dimension. 2020; 22(1):13-21.

[11] Ruggieri S, Perrone D, Leone M, Uva G, Aiello MA. A prioritization RVS methodology for the seismic risk assessment of RC school buildings. International Journal of Disaster Risk Reduction. 2020.

[12] Reddy MD, Jeyashree TM, Reddy CD. A case study on vulnerability risk assessment of buildings in chennai using rapid visual screening. Annals of the Romanian Society for Cell Biology. 2021; 25(5):218392.

[13] Parmar A, Patel VM, Singh AP. Seismic vulnerability assessment of buildings in Surat city of western India. International Journal of Innovative Technology and Exploring Engineering (IJITEE). 2019; 8(10):719-23.

[14] Calvi GM, Pinho R, Magenes G, Bommer JJ, Restrepo-vélez LF, Crowley H. Development of seismic vulnerability assessment methodologies over the past 30 years. ISET Journal of Earthquake Technology. 2006; 43(3):75-104.

[15] Ramly N, Ghafar M, Alel M, Adnan A. Rapid visual screening method for seismic vulnerability assessment of existing buildings in Bukit Tinggi, Pahang, Malaysia. In international conference on advances in civil, structural and mechanical engineering, birmingham 2014.

[16] Sarraz A, Ali MK, Das DC. Seismic vulnerability assessment of existing building stocks at Chandgaon in Chittagong city, Bangladesh. American Journal of Civil Engineering. 2015; 3(1):1-8.

[17] Modi R, Mohan K. Rapid visual screening of RC frame buildings in 2001 Bhuj earthquake affected Rambaug area of Ahmedabad, Gujarat. Editorial Office. 2019; 23(2):143-51.

[18] Sadat MR, Huq MS, Ansary MA. Seismic vulnerability assessment of buildings of Dhaka city. Journal of Civil Engineering. 2010; 38(2):159-72.

[19] Joshi GC, Kumar R. Preliminary seismic vulnerability assessment of Mussoorie town, Uttarakhand (India). Journal of Building Appraisal. 2010; 5(4):357-68.

[20] Dutta SC, Nayak S, Acharjee G, Panda SK, Das PK. Gorkha (Nepal) earthquake of April 25, 2015: actual damage, retrofitting measures and prediction by RVS for a few typical structures. Soil Dynamics and Earthquake Engineering. 2016; 89:171-84.

[21] Sarmah T, Das S. Earthquake vulnerability assessment for RCC buildings of Guwahati city using rapid visual screening. Procedia Engineering. 2018; 212:214-21.
[22] Rautela P, Joshi GC, Bhaisora B, Dhyani C, Ghildiyal $S$, Rawat A. Seismic vulnerability of Nainital and Mussoorie, two major lesser Himalayan tourist destinations of India. International Journal of Disaster Risk Reduction. 2015; 13:400-8.

[23] Shakya M, Kawan CK, Gaire AK, Duwal S. Postearthquake damage assessment of traditional masonry buildings: a case study of Bhaktapur municipality following 2015 Gorkha (Nepal) earthquake. Engineering Failure Analysis. 2021.

[24] Aldemir A, Guvenir E, Sahmaran M. Rapid screening method for the determination of regional risk distribution of masonry structures. Structural Safety. 2020.

[25] Halder L, Dutta SC, Sharma RP. Damage study and seismic vulnerability assessment of existing masonry buildings in Northeast India. Journal of Building Engineering. 2020.

[26] Sobaih ME, Nazif MA. A proposed methodology for seismic risk evaluation of existing reinforced school buildings. HBRC Journal. 2012; 8(3):204-11.

[27] Dasgupta S, Mukhopadhyay B. Historiography and commentary from archives on the Kathmandu (Nepal)-India earthquake of 26 August 1833. Indian Journal of History of Science. 2015; 50:491-513.

[28] http://bsdma.org/Publication-Reports.aspx. Accessed 05 September 2021

[29] http://bsdma.org/Publication-Reports.aspx. Accessed 05 September 2021.

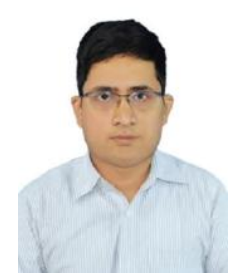

Siddharth has done his B.E in Civil Engineering from RV College of Engineering,Bengaluru.He completed his M.E with specialization in structural Engineering from BIT Mesra.Presently he is pursuing his Ph.D from NIT Patna $\mathrm{He}$ is a member of earthquake safety clinic and centre at NIT Patna. His research area includes Vulnerability Assessment and Retrofitting of Buildings.

Email: siddharth.phd18.ce@ nitp.ac.in

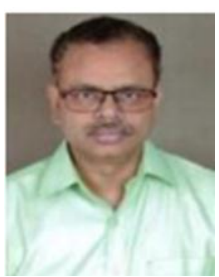

Ajay Kumar Sinha is presently Professor, Civil Engineering Department, National Institute of Technology Patna. He has 35 years of teaching and research experience. He obtained his B.Tech degree from IIT BHU in 1986, M.E. in Earthquake Engineering from IIT Roorkee in 1989.

He completed his PhD from Delhi College of Engineering, University of Delhi. His research interests include Seismic resistant structures, Vulnerability Assessment and Retrofitting of structures, Structural Health Monitoring, Reliability Engineering. He is centre Director cum Nodal Officer of Earthquake safety clinic and centre at NIT Patna. $\mathrm{He}$ is a member of the Earthquake Committee of BSDMA, GoB, Patna. He has published over 150 research Paper 
International journals and conferences. He has supervised 5

$\mathrm{PhD}$ and $55 \mathrm{ME}$ students with $10 \mathrm{PhDs}$ undergoing.

Email: aks@nitp.ac.in

\begin{tabular}{lll}
\multicolumn{2}{l}{ Appendix I } & \\
\hline S. No. & Abbreviation & Description \\
\hline 1 & RVS & Average Recurrent Interval \\
\hline 2 & URM & Unreinforced Masonry
\end{tabular}

Appendix II

The data collection form utilized for field survey (IS 13935:2009)

\section{RAPID VISUAL SCREENING OF MASONRY BUILDINGS FOR SEISMIC HAZARDS}

Seismic Zone $V$

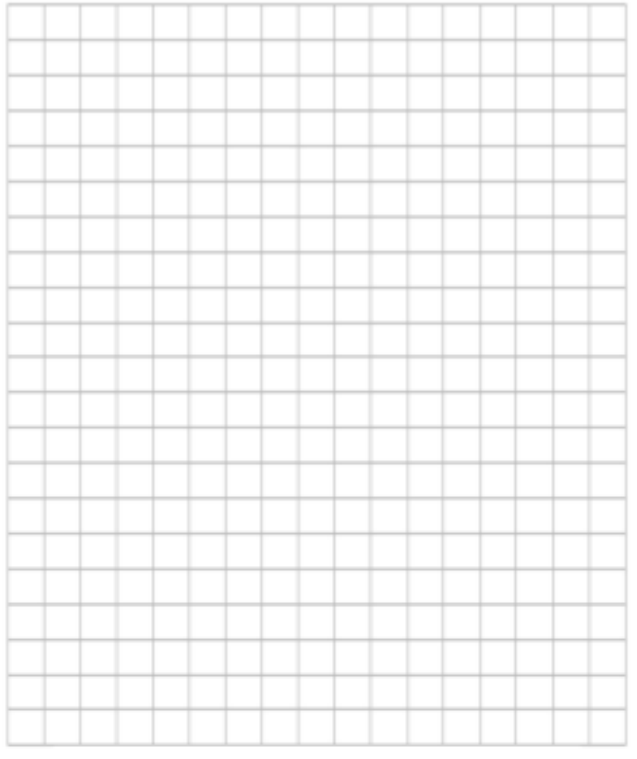

Sketch Plan with Length and Breadth

1.1 Building Name:

1.2 Use:

1.3 Address:

1.4 Other Identifiers:

1.5 No. of Stories

1.6 Year Built

1.7 Covered Area; all floors (sq. m)

1.8 Ground Coverage ( $\mathrm{Sq} . \mathrm{m}$ ):

1.9 Soil Type:

1.10 Foundation Type

1.11 Roof Type:

1.12 Floor Type

1.13 Structural Components:

1.13.1Wall Type: BB* [ ] Earthen [ ] UCR* [ ] $\mathrm{CCB}^{*}$ ] [ ]

1.13.2 Thickness of wall

1.13.3 Slab thickness

1.13.4 Mortar Type: Mud [ ] Lime [ ] Cement [ ]

1.13.5 Vert. R.F bars: Corners [ ] T-junctions [ ] Jambs [ ]

1.13.6 Seismic bands: Plinth [ ] Lintel [ ] Eaves [ ] Gable [ ]

*BB - Bumt Brick, "UCR - Uncoursed Random Rubble

*CCB: Cem ent Concrete Block

\begin{tabular}{|c|c|c|}
\hline 2.0 OCCUPANCY & 3.9 SPECIAL HAZARD & $\begin{array}{l}\text { 4.0 FALLIING } \\
\text { HAZARD }\end{array}$ \\
\hline 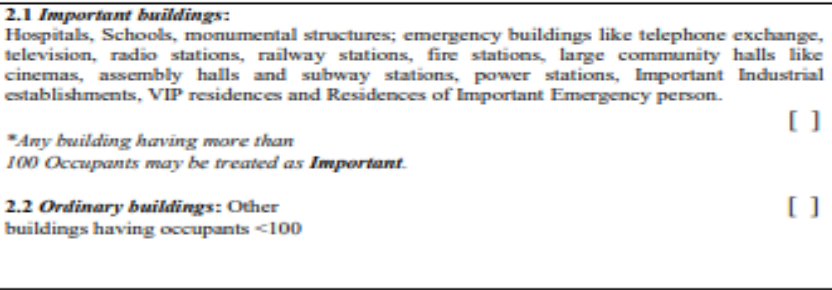 & 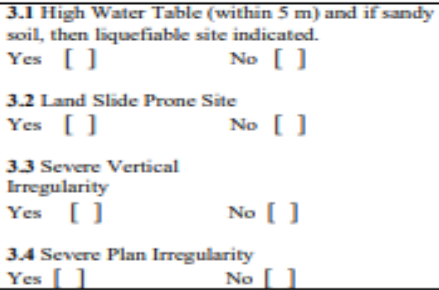 & $\begin{array}{l}\text { 4.1 Chimneys [ ] } \\
\text { 4.2 Parapets [ ] } \\
\text { 4.3 Cladding [ ] }\end{array}$ \\
\hline
\end{tabular}

\subsection{Probable Damageability in Few/Many Buildings}

\begin{tabular}{|c|c|c|c|c|}
\hline Buildings & & Mast & fing & \\
\hline $\begin{array}{l}\text { Damage- } \\
\text { ability in }\end{array}$ & $\mathbf{A} / \mathbf{A}+$ & $\mathbf{B} / \mathbf{B}+$ & $\mathrm{C} / \mathrm{C}+$ & D \\
\hline & $\mathrm{G5} / \mathrm{G} 4$ & $\mathrm{G5} / \mathrm{G} 4$ & $\mathrm{G} 4 / \mathrm{G}$ & G.3 \\
\hline
\end{tabular}

Note: + sign indicates higher strength hence somewhat lower damage expected as Also stated. Average damage in ane building type in the area may be lower by one grade pount than the probabile damageabuliny indicatied.

Surveyor will identify the Building Type: encircle it, alvo the corresponding

Damage grade.

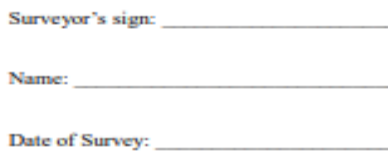

